\author{
И. А. Подюков \\ Пермский государственный \\ гуманитарно-педагогический университет \\ Пермь, Россия \\ podjukov@yandex.ru
}

\title{
Словарь похоронно-поминальной обрядности русских Прикамья как источник сведений о региональных особенностях традиции*
}

По мнению исследователей, традиционный похоронный обряд русских разных регионов России в целом однороден, лишен ярко выраженных локальных вариантов [Русский Север, 661], а связанный с ним лексикон (прежде всего в силу табуированности многих представленных в нем понятий) отличается «относительной бедностью вербального оснащения» [Толстая, 2008, 441]. Консерватизм обрядности, напрямую связанной с человеческой экзистенцией и высокими эмоциональными потрясениями, свидетельствует о том, что изменение отношения человека к смерти заметно лишь в исторической ретроспективе. Универсальные архаичные представления о смерти сохраняются и в позднее время, несмотря на христианское влияние, социально-культурные изменения в обществе и разрушение сакральной культуры как таковой.

На разных территориях отмечаются прямые соответствия лексики и фразеологии обрядов, связанных со смертью. Так, выражение пора на веники 'о близости смерти' известно как ярославское и пермское [СРНГ, 4, 114]; название тайная (тихая, потайная) милостыня 'раскладывание под окнами, на крыльцах соседей даров в память об умершем' известно у старообрядцев Прикамья, в русской речи Дальнего Востока, в русских старообрядческих селах Турции, Румынии, Болгарии, Грузии [Тульцева, 2002]; название пелены и льняного пояса для пеленания умершего свивальник (от свивать 'повивать, пеленать') отмечено у забайкальских и пермских староверов.

В то же время языковые факты позволяют увидеть неравномерность изменения отдельных сторон обрядности, особенности ее

\footnotetext{
* Исследование выполнено в рамках проекта РФФИ № 18-412-590002 p_a «Похороннопоминальная обрядность в русской традиции Северного и Южного Прикамья».
}

(С) Подюков И. А., 2019 
регионального развития. Наиболее заметна локальная специфика номинаций, основанных на развертывании обрядового символизма. Так, выражения в березки (в березку) пора 'о крайне старом человеке', на выходе в березки 'о готовящемся умирать', до березки 'до смерти' основаны на образе березы, известном маркере сакрального локуса (параллелизм «смерть - береза» устойчив в разных культурах, в частности отмечен в английской символике народных баллад и шекспировских текстов [Макулина, 1987, 106]). Эти же ассоциации мотивируют архангельское выражение на березку забираться 'умирать' [АОС , 15, 91].

К трансформации обрядов и, соответственно, изменению терминосистемы могут приводить социальные процессы. Пермское название женщины, которая принимает исповедание и причащает умирающего святой «иорданской» водой, прощальнища отмечено у часовенных староверов (г. Верещагино); обычно это функция мужчины-наставника. Обряд в нынешних условиях (если наставник далеко или его нет совсем) может выполнять хорошо знающая веру женщина из близкой умершему среды. Исчезновение института чи́тальщиц и замена похоронных причитаний на тексты, восходящие к книжной традиции, мотивирует появление глагола стихарить (Юрла) 'петь духовные стихи в обряде сороковин (проводов души)'.

В локальной традиции может получить особую продуктивность тот или иной способ образования обрядовых терминов. Так, разнообразны в пермских говорах наименования обрядовых реалий, созданные переходом прилагательных в разряд существительных (часто в форме ср. p., которая обеспечивает элемент обобщенности): встречное, хлебное 'подаяние первому встретившемуся похоронной процессии', поминное ‘поминальное блюдо', проходное 'повязка с церковными молитвами, которую кладут умершему в гроб', смёртное 'приготовленная для погребения сряда', полотенешное 'ткань, на которой несут гроб' (ср. в свадебном обряде вставальное, вышибальное, подножное, в строительном - коньковое 'угощение при завершении строительства дома'). Определенное своеобразие локальной обрядовой терминосистеме придают редкие заимствования из языков народов, с которыми контактировали русские. Таково название поминальной каши-кутьи уразница (Кунгурский район Пермского края). Слово восходит не к слав. ураз 'увечье, рана', а к тюркскому названию мусульманского поста ураза (его держат в том числе и за умершего близкого родственника). 
Несмотря на современную формализацию и редукцию обрядов похоронно-поминального круга, в них еще достаточно ощутимы архаические элементы сакральности. Пространственная закрепленность данного вида народной культуры, как и неравномерность ее развития и разрушения, проявляется в словаре, отличающемся региональными особенностями.

АОС — Архангельский областной словарь / под ред. О. Г. Гецовой. М., 1980-. Вып. 1-.

Макулина Л. Т. Национально-культурный символизм в лексико-семантическом аспекте // Лексическая семантика и фразеология. Л., 1987. С. 103-110.

Русский Север: этническая история и народная культура XII-XX веков / отв. ред. И. В. Власова. М., 2001.

СРНГ - Словарь русских народных говоров / гл. ред. Ф. П. Филин (вып. 1-22) ; Ф. П. Сороколетов (вып. 23-42) ; С. А. Мызников (вып. 43-). М. ; Л. ; СПб., 1965-. Вып. 1-.

Толстая С. М. Пространство слова. Лексическая семантика в общеславянской перспективе. М., 2008.

Тульцева Л. А. Тайная милостыня // Православная вера и традиции благочестия у русских в XVIII-XX веках : этнографические исследования и материалы / отв. ред. О. В. Кириченко, Х. В. Поплавская. М., 2002. С. 90-100.

DOI $10.31168 / 7996-2700-3.97$

\section{С. А. Попов}

Воронежский государственный университет

Воронеж, Россия

spo@bk.ru

\section{О лексикографическом обеспечении региональных ономастических исследований}

В последнее время в российском обществе наблюдается повышенный интерес к фактам местной истории и культуры. Во многих субъектах Российской Федерации значительно увеличилось количество краеведческих исследований. Не только ученые, но и местные жители стали активнее обращаться к изучению региональных ономастических

(C) Попов С. А., 2019 